\title{
Giuseppina Pizzigoni and the Experience of the "Rinnovata" School: An Emblematic Pedagogical Figure in the Italian Panorama of the Early Twentieth Century
}

\author{
Alessandra Natalini \\ Primary School Teacher, Rome, Italy \\ Email: drana@hotmail.it
}

How to cite this paper: Natalini, A (2021). Giuseppina Pizzigoni and the Experience of the "Rinnovata" School: An Emblematic Pedagogical Figure in the Italian Panorama of the Early Twentieth Century. Open Journal of Social Sciences, 9, 255-284. https://doi.org/10.4236/jss.2021.96020

Received: May 22, 2021

Accepted: June 22, 2021

Published: June 25, 2021

Copyright $\odot 2021$ by author(s) and Scientific Research Publishing Inc. This work is licensed under the Creative Commons Attribution International License (CC BY 4.0).

http://creativecommons.org/licenses/by/4.0/

(c) (i) Open Access

\begin{abstract}
The aim of this contribution is to explore the emblematic figure of Giuseppina Pizzigoni, pedagogue and teacher, who worked in Italy at the end of the 19th and beginning of the 20th century. This pedagogist lived and worked as a teacher in a historical-cultural context characterised by the development of Positivism, a moment in which the need for greater scientific rigour in education was affirmed. The definition of the method and the object of study, the observation, the collection of data, the formulation of a hypothesis or a plan of action, as well as its application, and the verification of results, are at the basis of the scientific method. From this Pizzigoni derived the assumptions of her approach and method, starting from the diffusion, especially in America and Northern Europe, of the Pedagogical Activism and of the experiences of the New Schools, based on the centrality of the child, on the respect for his person and his integral development: physical, mental, affective and relational. This has made her approach highly topical and of great interest to researchers in recent years, especially because of what she says about the relationship between culture and nature in education. The "Fondo Pizzigoni" today constitutes a pedagogical heritage of enormous value and interest.
\end{abstract}

\section{Keywords}

Giuseppina Pizzigoni, "Rinnovata”, Attivismo, Scuole Nuove, Insegnamento

\section{Introduction}

The present contribution explores the emblematic figure of Giuseppina Pizzigoni, pedagogue and teacher, who worked in Italy at the end of the 19th and be- 
ginning of the 20th century. Starting from a historical-critical analysis, it analyzes the original texts of Giuseppina Pizzigoni and identifies the relevant and innovative aspects of her thought and her educational practices, interpreted in the light of the relationship between man, culture and nature.

An emblematic figure of Italian pedagogy of the late nineteenth century early twentieth century, Giuseppina Pizzigoni lived and worked as a teacher in a historical-cultural context characterized by the development of Positivism, which affirmed the need to assume greater scientific rigor on the educational level, implying the definition of the method and object of study, observation, data collection, formulation of hypothesis or action plan, as well as its application, and verification of results.

Positivism also led to the spread, especially in America and Northern Europe, of pedagogical activism and the experiences of the New Schools (Codignola, 1948), based on the centrality of the child, on respect for his person and for his integral development (physical, mental, affective and relational). Pizzigoni is part of this movement of innovative pedagogical experiences, born from the desire to bring about profound and incisive changes within the traditional school, with reference above all to the "constriction" of the classroom.

With her came the birth and spread of "open-air schools", in which the child was placed at the centre of the educational process and in concrete contact with nature (Chistolini, 2016). It is worth emphasising here how the processes of modernisation and industrial fervour taking place at this time in Milan (the engine of the Italian economy and capital of culture, where the Politecnico was founded in 1863 and the Bocconi University in 1902), and in other parts of Italy, as well as the processes of industrialisation, urbanisation, overcrowding, migration and poor hygiene, led to the transformation and emergence of new social needs.

From a political point of view, it can be observed that at the moment in which Pizzigoni became a teacher, the Coppino Law (1877) was in force in Italy, according to which the elementary school, lasting five years, provided for compulsory schooling for only the first three years (with a penalty for those who do not comply). Later, the elementary school programs of 1888 emphasized the need for the experimental method and the "lessons of things".

Subsequently, the Law of 1877 was replaced by the Orlando Law (1904), which passed the compulsory schooling from three to six years (up to twelve years) and established that elementary education had a duration of four years, at the end of which the final exams took place to pass to secondary school or to a "popular course". The latter formed by class V and VI, for those who wanted to start working. This course will later be replaced by the "professional training school" in 1928 with the Consolidated Law.

The Orlando Law was in turn replaced, first by the Daneo-Credaro Law (1911), which transformed the elementary school into a state school (no longer municipal) and established municipal school patronages to help children in need 
to fulfill their compulsory schooling, and, later, by the Gentile Law (1923).

Giovanni Gentile, then Minister of Public Education, brought the compulsory schooling up to the fourteenth year of age by providing for five years in elementary school, preceded by a three-year preparatory course: "the nursery school" (today kindergarten). The "popular course" was thus extended to three years and took the name of "supplementary vocational training classes", which would later become "secondary vocational training school" with the law of 22 April 1932. It should be noted that the teaching of the Catholic religion was restored in elementary school.

\section{Giuseppina Pizzigoni and the "Outdoor School"}

Giuseppina Pizzigoni worked in a cultural and social climate of great change. She was born in Milan on March 23, 1870 to the professor of foreign languages Carlo Pizzigoni and Virginia Bossi. Older than four sisters, she was influenced by her maternal example, dedicating herself to the education of children. She is a restless, passionate and intolerant child, she right from the start to the monotonous life perpetrated by the traditional school and profound lover of the theater.

However, her dissatisfaction and aversion to the passive and notional system of the traditional school remained with her even when in 1888 she obtained her master's degree. After winning the competition, she embarked on a career as a teacher in Milanese elementary schools (in 1888-1889), thanks also to the support of her mother (Pizzigoni, 2013: pp. 1-7).

Inspector Luigi Friso described Pizzigoni as "a tall, slim woman" with a "restless body, always tending to movement [...] a strong nose: and behind the glasses [...] two black eyes, sharp, shining, searching, observing, scrutinising, and saying a great faith [...] faith in human improvement by virtue of education, when this is so strong and so healthy as to give the individual mastery of himself and of events" (Friso, 2017: p. 3).

Around 1910 Pizzigoni, accompanied by her friend and colleague Maria Levi, made some trips to Europe to visit outdoor schools especially in Switzerland, Alsace (north-eastern France, on the border with Germany and Switzerland) and Mülhausen in Germany. She noticed a great deal of attention to physical education, sports exercises and hygiene in these schools, but soon realised that they were still understood as a kind of "sanatorium-schools", that there was no application of the experimental method and that they were all private and intended for the "rich".

Following these trips, Pizzigoni's desire to return to Italy grew to open a real "outdoor school", free of charge, open to all children and based on direct contact with nature and the experimental method, which would pay attention to the direct experience of the child, to the observation of reality and the surrounding environment, to play and work activities, and above all to contact with nature. The latter was to be considered the foundation of the child's integral formation, 
aimed at making him or her aware of being a man, the personal appropriation of the elements of reality and self-education. Pizzigoni herself declared that her aim was to "invent something that does not exist; I would like what I do not have" (Pizzigoni, 1946: p. 1).

In 1911 he founded the "Rinnovata" in the Ghisolfa distr ct of Milan, a proletarian suburb in the northern part of the Municipality of Milan. Within this school, two mixed sections of first class were initially opened next to the municipal school, each of which made up of 30 children, 15 boys and 15 girls, aged six, who soon increased in number, passing from 64 children in 1911-1912 to 121 in the year 1912-1913. The rapid increase in students led to the need and construction of a new school building, which was inaugurated on October 30, 1927 and which still exists today.

Already in 1921 Giuseppina Pizzigoni, teacher and pedagogist, obtained the title of director and was awarded the Medaglia d'oro dei benemeriti dell'istruzione e la stella al merito della scuola. In 1922 her volume was published Linee fondamentali e Programmi della scuola elementare "Rinnovata" secondo il metodo sperimentale [Fundamental Lines and Programs of the elementary school "Rinnovata" according to the experimental method]. Subsequently, in 1927, she took care of opening a "Kindergarten", which followed her method and was based on freedom, play and respect for the natural development of the child. She was guided by an idea of education that would allow the child to live "as a real child" (Pizzigoni, 1929: p. 6) and to grow "according to truth and according to nature" (Pizzigoni, 1929: p. 8).

In 1929 Pizzigoni, having retired from the direction of the school, published II mio Asilo infantile. Linee fondamentali. Programma. Orario. Note illustrative [My Kindergarten. Fundamental lines. Program. Schedule. Explanatory notes], in which some central aspects of her method are present. Continuing to devote herself to the dissemination of her own experimental method (or method of personal experience) and organizing training courses aimed at future teachers and the "corso annuale ai Maestri d'Italia" ["annual course for the Masters of Italy"], in 1931 she published the work Le mie lezioni ai maestri [My lessons to the masters of Italy], which briefly outlines its pedagogical ideas and the respective programmatic lines for the various disciplines. It should be emphasized that, during the advent of Fascism, which progressively took over the school for propaganda purposes, the work at the "Rinnovata" School was not actually hindered, but this experience created a radical break between two incompatible educational concepts, that is: the first, promoted by Pizzigoni and based on concepts of freedom, spontaneity and respect for the child; and the second, the fascist one, based on authority, obedience and heteronomy (Nicoli, 1947: pp. 146-147). This is also demonstrated by the fact that Pizzigoni, during her Duce's visit, refused to wear the uniform, showing her dissent for the interference of politics in the school. Pizzigoni died in the hospice of "Sant'Anna" in Saronno in Lombardy on 4 August 1947, an occasion on which the city of Milan paid her 
homage, taking her remains to the Monumental Cemetery and dedicating a street to her.

In Italy we owe the birth and spread of "open-air schools", which concretely took the classroom beyond the school walls.

\section{A Female Pedagogy}

In the pedagogical climate of those years, a "female" pedagogy was established, which, especially in Italy in the early twentieth century, became very pronounced. In this regard, it should be remembered that, alongside Giuseppina Pizzigoni, stands the experience of other important scholars such as the Agazzi sisters, Maria Boschetti Alberti and Maria Montessori. However, it is with the scientific pedagogy of the latter, known as the "Doctor", and with the careful and objective teaching of Giuseppina Pizzigoni, educator known as the "Lady", that a female pedagogy is established, that sees the two pedagogists commit themselves, with different aspects and resonances, to change the school of the beginning of the Century.

In fact, if Montessori is considered a woman of the public and of undoubted fame, whose thought has had an international echo, Pizzigoni can be said to be a "school woman" who has implemented a great educational "Rinnovata" in Italy and which has had great diffusion for various reasons:

- related to gender (which make it difficult for a woman to bring innovative ideas);

- cultural (a cultural climate of contrast between positivism, neo-idealism and spiritualism);

- disaffection towards the study of an inadequate (ancient) school (attention must be paid to understand the real "Rinnovata" especially at the cultural level of the "Rinnovata");

- distance between university pedagogy and school pedagogy; communication, which selects and does not disseminate information deemed of little interest to the mass, understood as an audience (Chistolini, 2009a: pp. 44-45).

Montessori and Pizzigoni, dedicating their lives to education, undertook to refine and develop their own "method", which can be said to be similar and distant at the same time. Similar in that both were attentive to the new social needs, observation, freedom, direct participation of the child and his integral formation as a source of progress for all humanity, but they were also very distant in defining the conditions and times. Learning of writing and reading (learning that Montessori introduces already in the first class, while Pizzigoni postpones them to subsequent years).

\section{The Use of the Experimental Method}

In order to understand Giuseppina Pizzigoni's experimental method and the importance of her innovative pedagogical experiment, it is necessary to remember that the historical and cultural context of Italy in which she worked was 
characterised by the presence of a traditional school based on verbalism, immobilism, notionism, the absence of a link or direct contact with reality and the life of the child and on the teaching of reading, writing and "counting"; in other word a school too focused on content and on the centrality of the figure of the teacher.

In fact, it is precisely from the dissatisfaction with this idea of a "stagnant" school, from the need to combat school verbalism, from the desire to reunite theory with practice, from the effective activity of educating the child as a whole and from a attention to her personality, without however neglecting the collective dimension, that Pizzigoni started a cultural revolution of the idea of school, starting from the observation of the importance of renewing the educational method and the learning environment. In this regard, De Bartolomeis (1953) states that Pizzigoni's merit was that of having given the alarm "for the sad conditions of the elementary school" (p. 16). Indeed, precisely in this direction, in her speech given in the Aula Magna of the Beccaria Gymnasium in 1911, which ended with widespread public consensus, Pizzigoni set out the main lines of her pedagogy for "the education of the people", convinced that "Rinnovata" was "born in order to show what the popular school should be" (Pizzigoni, 1921: p.

3), starting precisely:

- from the environment, understood as "a simple building, which in itself, in its architectural lines, in its furnishings is worthy of giving the studio house a severe and serene concept, is useful in facilitating every school duty and educating the aesthetic sense" (Pizzigoni, 1911: p. 8);

- from the teaching method, called "experimental method" or "personal experience method", or "a process of observations and experiments, of inductions and deductions; it is the natural method par excellence" (Pizzigoni, 1911: p. 10).

In the volume Le mie lezioni ai maestri delle scuole elementari d Italia [ My lessons to the teachers of the elementary schools of Italy] (1931), Pizzigoni defines her own method that "takes few words and many facts; active life of the child in contact with many things and with many facts and with many people. The few words of the teacher must guide the pupil to good impressions, they must clarify, correct where necessary [...]. The 'Rinnovata' method puts in the first place giving strength to the body and spirit of the pupil through the life of the school, which is of rich experience" (Pizzigoni, 1931: p. 35). Taking up the terminology of Galileo Galilei, Pizzigoni's "experimental method" is based on the direct experience and the active activity of the child, leaving the latter free to try, touch, to deduce, to do etc., on the observation and analysis of the surrounding environment, on teaching the child to ask himself questions and seek answers, on personal research and the student's discovery and aims to address a few concepts and information (inductive method), but clear, precise and progressively linked to each other.

From the attention to the developmental stages of the child, she derives a teaching defined as "cyclical", which allows a gradual deepening of what is being 
addressed, passing from concrete and intuitive facts to abstract concepts. For the pedagogist it was necessary to take into consideration the interests of the child, to allow him to learn with pleasure and with a spontaneous interest, never forgetting what she has learned with the effort and "the joy of discovery" (Nicoli, 1947: p. 54).

It is an "effective" and "natural" method, attentive to the activity and movement of the child, to his interests and to his physical and bio-psychological needs, in which the main educational objective becomes the spontaneous, harmonious and of the child, as a person and member of society. This method allows the individualization of learning, respect for the rhythms and times of each child and above all guarantees the child, the development of his peculiarities, autonomy, sense of responsibility, self-education and the economy of mental forces. It implies love and respect for childhood and the child's personality, his creativity and his freedom, relying on his spontaneous attention, which, unlike the desired attention, arises from the immediate interests of the child and not. it takes too much effort.

The means used by the method "of personal experience" are therefore life and work: "Study is life: life is movement, and children need movement so much!" (Pizzigoni, 1911: p. 9; Pizzigoni, 1911: p. 9) and the school "must prepare for life and not for exams" (Pizzigoni, 1914a: p. 13). Pizzigoni's experimental method is "with a high social impact because it refers to the school environment in terms of the world" (Chistolini, 2009a: p. 51) and sees the internal environment in continuous contact with the external one with the aim of forming "robust men, lovers of work, able to dominate and direct their own will, who know their country well, their individual needs and those of the society they belong to, and conform their natural tendencies and the necessary sacrifices to them" (Pizzigoni, 1914a: p. 7).

Pizzigoni appears as a woman "with a strong sense of national identity" and a "profound social sensitivity" (Chistolini, 2009a: p. 125), so much so that schools are considered as a "small society", in which one learns the value of hospitality and respects others and develops a mental attitude of openness to the world.

For this pedagogist, "school is the world". It is necessary to bring the latter to school (Pizzigoni, 1914b: p. 6), an aspect that she realizes when "we leave the world of words and enter the world of facts" (Pizzigoni, 1920: p. 7). The school is understood by her as a natural and human environment "as extensive and rich as possible" (De Bartolomeis, 1953: p. 19), in which trips and educational trips and a learning place rich in experience find their place introducing laboratories and workshops (carpentry, mechanics, etc.) within the school. The attention to empiricism leads her to affirm that "everything is objective teaching, since every teaching has as its purpose the knowledge of an object, that is the knowledge of one of the innumerable things that make up the universe" (Pizzigoni, 1920: p. 6).

This teaching involves a procedure that begins with the child's keen interest, followed by the spontaneous observation of the child and observation guided by 
the teacher, up to the opinions expressed in verbal form, first guided by the teacher and then autonomous, and individual written practice, including memory training. In this sense, the teachings were configured as real "conversations" that relied on "centers of interest", understood as centers of knowledge that the teacher must constantly search for.

It thus departs from the "centers of interest" and from the meaning used by Ovide Decroly (1962), who defines them as the four elementary interests-needs (Cassottana, 1988: p. 39). In relation to work, understood as a complete expression of the need to live, to act, to vitality, as well as an important means of education and "necessity and happiness of life" (Rompato, 1927: p. 39). As "the dominant and necessary passion of life, a synthesis of practical and speculative skills and the manifestation of the whole personality" (Cassottana, 2004: p. 141), work is therefore the basis of physical, intellectual, moral, aesthetic, religious education etc. It allows the physical development and the sense of ownership, responsibility, health, self-discipline and trust in one's resources, as well as allowing the active participation and enrichment of the linguistic vocabulary up to understanding how the foundation of life work (Pizzigoni, 1911: p. 10).

Great importance in this regard is given to manual and land work, which is conceived "as a skill of the hand and as an education to work, [which] it is indispensable for those who will become the active force of the nation" (Pizzigoni, 1914a: p. 10); it can be developed through gardening and caring for animals, but also by doing paperwork, with clay, with twine, with wool, with wood, etc., or by working with milk, creating coal, bread, the herbarium etc. All activities allow you to learn important geometric and mathematical concepts (geometric figures, accounting concepts) and related to the Italian language (through the diaries of the work that is carried out daily) (Pizzigoni, 1940: pp. 13-83).

The experimental method, therefore, transforms the disciplines of the ministerial programs into sources of multiple experiences and the school into life. It is applied to every educational area and brings with it the need to renew learning spaces and times.

Another innovative aspect of the "method" consists in the extension of the school timetable, which united school and after-school, so much so that Pizzigoni herself speaks of it, arguing that the time of the "Rinnovata" is at indefinite limits, as indefinite limits are, in a sense, its program and its method; it "begins and ends with the needs of the pupil [...]. Someone said: What a long time!" (Pizzigoni, 1940: p. 19).

This well-distributed, flexible and extended timetable not only allowed lessons to be conducted according to the experimental method, but also met precise methodological and educational requirements, adapting to the socio-cultural needs of Milanese families at the time. This aspect is to be considered an element of great innovation, especially if we take into account that scientific studies, which will demonstrate the impact of the socio-cultural context on the intellectual development and school performance of children, will become established 
later, in other countries, around the 1920s-30s, and in Italy, around the 1960s.

In this interpretative key, the method conceived the integral formation of the child, didactic flexibility and individualization of teaching, but also aimed to avoid mental fatigue of the pupil, respecting the bio-psycho-physical rhythms, in the conviction that all children had the same basic needs, such as, for example, work, rest, good example, exercise, open air, etc. For these reasons, in the morning there was a cleanliness check and they did "reading, writing, arithmetic and language exercises, which were nothing more than a kind of summary of their lives lived by working, walking or experimenting" (Pizzigoni, 1914b: p. 11).

In the afternoon the children were engaged in manual work, gardening, music, singing, gymnastics, drawing and other outdoor activities. In addition, the time followed the scanning of the seasons, from 9:00 to 17:00 in winter and from 8:30 to 17:00 in summer, with rest of about two hours at lunchtime around noon, at which time the children eat and rest, possibly outdoors. At 10:30 the snack for the snack marked the morning activity, together with the breakfast at 12 and the afternoon snack at 16, thus showing a special attention to nutrition. The school remained open all year, for ten months, with suspension of lessons for ten days during the Christmas holidays, for ten days in the Easter period and for a period that went from the second half of July, including August and the first mid-September. It was also closed every Sunday, with Thursday optional, and provided for 40 hours per week, of which 13 of rest.

Alongside all this organization, it should be remembered how, in 1918, Pizzigoni opened a hygiene colony for those who were unable to go to the countryside during the summer.

Regard to the learning environment, the latter had to be rich in educational stimuli, soliciting problems and questions, coming to coincide precisely with "the world": "the school environment for a school that wants to put schoolchildren in contact with the world is [...] the world" (Pizzigoni, 1914a: p. 38).

Thus Master "is every natural fact and every man. Do not teach: experiment" (Pizzigoni, 1922: p. 3) and where "wherever there is reason for study" (Pizzigoni, 1931: p. 26) whether it is transposed to the countryside, mountains, workshops, factories, museums, city etc. The Pizzigoni environment differs from the pre-ordained Montessori one and extends, welcoming within itself all its possible meanings, in such a way as to "make the school overcome the narrow confines of the classroom" (Cassottana, 2004: p. 93) and to become a solicitor of problems that the child is eager to answer.

It is a serene, stimulating environment, neat and tidy in all its aspects, so that parents can be sure to leave their children there and through it the children can receive an aesthetic education, surrounded by beauty (which is also linked to goodness). In the "Rinnovata" there were carefully selected furnishings, such as vases with flowers and pictures of natural landscapes, portraits of important people, paintings by artists, both coloured and black and white. The importance assumed by the environment also emerges from the words of De Bartolomeis, who declared that "for Pizzigoni, the environment is the main source of know- 
ledge" (De Bartolomeis, 1953: p. 25) and the school "the natural and human environment" that "she wants as extensive and rich as possible" (De Bartolomeis, 1953: p. 19).

At "Rinnovata", the child's direct contact with nature was considered a privileged tool, as a source of intellectual, moral and aesthetic education. With reference to intellectual education, direct contact with nature allows the child to learn new knowledge in various fields, such as linguistic, historical and geographical (through travel and walks), scientific, artistic, at the same time favoring both psychic and physical wellbeing, health and social relations. At the same time, nature is considered a teacher of life and an inexhaustible source of moral and aesthetic education, which encompasses and connects both the beautiful and the good. In this sense, nature becomes the primary source of "religious sentiment" and natural beauties are seen as the work of God and absolute perfection through which divine attributes are perceived (similar thought of Frederich Fröbel, 1993; Pizzigoni, 1931: p. 79). Nature is "an inexhaustible teacher; it is the great book always open to all those who know and want to read it [...] natural teacher" (Boranga, 1925: p. 7); the "great book of nature, which is a book of truth" (Pizzigoni, 1931: p. 103).

\section{School Is Life}

At the center of the idea that school is life, Pizzigoni places the child as the protagonist and effective builder of his own knowledge, which educates himself (as for Activism), even by coming into contact with anyone who can be his teacher (nature, such as plants, animals, rivers, companions, lakes, etc., but also industrialists, workers, fishermen, etc.). At the "Rinnovata" there are both class teachers and "expert" teachers, such as music or gardening, with the task of collaborating and communicating with each other in order to guarantee an integral formation of the child's personality in a logic of methodological continuity of the teaching-learning (overcoming the teacher's encyclopedism) at different levels of education, from pre-school to professional.

The teacher is therefore a guide, who has truth as his goal and who solicits and arranges means and tools so that the child's personal experience can be realized, paying attention at the same time to his interests and needs and helping him to attribute meaning and systematize his acquaintances (Cassottana, 2004: p. 211).

Among the characteristics that a teacher should possess, Pizzigoni recalls: "knowledge of child psychology, individual and collective; aptitude to live the life of the small world; mind trained in the knowledge of nature and social and national life; knowledge of the method criterion in the development of the various sciences, and great interest in childhood considered in itself, in its continuous development and in the future it will reach: here are in my opinion the essential elements for the formation of the truly renewed primary school teacher" (Pizzigoni, 1914a: pp. 13-14).

Consequently, the teacher is like a "magnifying glass" who respects the child, 
learns to know him and stimulate his desire to conquer the truth, leading him to "conquer his world" (Chistolini, 2009a: p. 81). A complex role of the teacher emerges, which requires continuous training. Pizzigoni took care of training teachers on the experimental method, first choosing the teachers she trusted and, later, fighting for the realization of real training courses.

Starting with the kindergarten, Pizzigoni shows great attention to the surrounding social context, characterized by the specific needs of the Milanese urban proletariat who work mainly for long hours in factories and who often lives in precarious overcrowding or poor hygiene conditions. As Pizzigoni herself declares, the Kindergarten arises to respond to a social need and is based on absolute love and respect for childhood to guarantee the child to live as a child respecting his needs and freedom (Pizzigoni, 1929: p. 5).

In addition to the importance of collaboration between teachers, the adoption of the principle of collegiality through general and particular meetings (between teachers of parallel classes) (Cassottana, 1988: p. 97) and the extension and flexibility of school hours, the pedagogist repeatedly reiterates the need to put the action of the school in continuity with that of the family, so much so that it provides moments of meeting, such as conferences, monthly interviews between the Management and parents (as established by article 20 of the Statute) and a "Festa del Lavoro" ["Labor Day"], which took place six times a year and which becomes a "collective and joyful expression of daily work" (Nicoli, 1947: p. 52). The moments of meeting between teachers and parents, the presentation of works, gymnastics competitions or other games, plays, etc. by children and, finally, allow parents to reflect on issues, such as hygiene, alcoholism, nutrition, etc. so that "the family becomes the complement of the school, since the school is nothing but the complement of the family" (Pizzigoni, 1911: p. 13).

This allowed and guaranteed a form of co-responsibility of the school and the family, in addition to the fact that the education and healthy lifestyle habits learned by the students also "extended" to their families, paying attention at the same time to the bond between parents and children. Through the elimination of homework, as the "Rinnovata" is a school that is "self-sufficient". The latter has the task of responding to the needs of families, in a context characterized by industrialization, the impossibility of taking care of the education of children and family obligations, poor hygiene conditions, problems related to alcoholism, etc.

Pizzigoni's great work can be summarized using her own motto, namely: "temple nature, aim the truth, method the personal experience of the boy" (Nicoli, 1947: p. 120).

Another fundamental aspect of his thinking is that concerning the fact that the flexibility and characteristics of the "Rinnovata" program designed to guarantee an integral and global formation of the person, which underlines the strong link between physical, intellectual, moral and aesthetic education and direct attention to the bio-psycho-physical needs of the child and his interests through a spontaneous and enjoyable education and activities such as play. The 
latter is intended as a "means of creative learning" (Chistolini, 2009a: p. 94) and is "that which while educating, entertains the spirit" (Pizzigoni, 1911: p. 17), allowing the child to observe and develop senses.

An elementary school without games can only be "lacking in a very effective didactic means", to be compared "to a day without sun" (Pizzigoni, 1911: p. 52). Therefore, a link emerges between play, learning and spiritual joy, of doing and knowing. In this regard, in his speech, on the occasion of the Symposium of 19 October 2002, Franco Frabboni underlines how Pizzigoni combines Fröbel's Idealism (1993) and Pestalozzi's Romanticism (1931): from the first, Pizzigoni takes up the concept of play as an integral experience and as a "peculiar form of knowledge and communication" of childhood, as well as a constant search for communication, expression and creativity in the child's daily experience through manual work, drawing, music (especially singing); from the second, she recovers some aspects, such as the fact that the activities of the spirit are those aimed at seeking and discovering reality, enriching itself with experiences, as well as the concept of nature understood as "dialectical integration between material and spiritual experience".

In his intervention Frabboni (2002) identifies seven "didactic pearls" of Giuseppina Pizzigoni's thought, namely:

1) the concept of experimental school and, in particular, the ability to relate theory and practice and the vision of the school as an "intentional project", not due to chance;

2) the concept of experience, which makes it possible to merge the explicit and implicit needs of the child and a learning that satisfies and follows them;

3) the concept of territory, as Pizzigoni's educational process starts from the child's life context and then reaches national and European contexts;

4) the idea of outdoor school, which emphasizes the educational value of observation, which becomes the center of learning;

5) the primacy of the scientific environment, as Pizzigoni binds the scientific world together with the concept of nature and, recovering the thoughts of Leonardo Da Vinci and Galileo Galilei, she underlines how observation and experimentation can lead to natural knowledge;

6) the dialectic between knowledge and relationship, between literacy and the affective-emotional dimension;

7) aesthetic education, understood as education in artistic sensitivity and the aspiration and pursuit of beauty (p. 1).

The novelty of the "Rinnovata" consists in "having put the experimental method in the necessary conditions of time and environment for it to work" (Friso, 2017: p. 16). On the other hand, Giuseppe Lombardo Radice, through what the children wrote in notes and observations, underlines how different this method is from the traditional school, where children are forced to write and express their feelings. He writes that the "Rinnovata" aims "to awaken observation and to obtain spontaneous expression [...] which will gradually become better organised and more complete and more reasoned. Here the pupil is searching for 
himself" (Lombardo Radice, 1925: p. 16) and for him to have "something to record, he must have had something to do" (Lombardo Radice, 1925: p. 5).

\section{Experimental Method, Disciplines and Materials}

Analysing the "Rinnovata" programme, one can see how the experimental method is developed and note not only the fusion of Idealism and Positivism and an "Activism inspired by a personalist vision" (Cassottana, 2014), but above all the desire to unite school and life, ensuring an integral formation of the child through the application of the experimental method.

As far as intellectual education is concerned, and especially language education, one cannot fail to notice how it arose from the life situations and experiences of the child, providing for the postponement of the learning of writing and reading for a year, so that the child would spontaneously feel the need, and the real necessity, to communicate to others what was observed and learned. In this way, the child was initially dedicated to developing his senses and learning vocabulary, grammar and the ability to express himself in his mother tongue through a variety of experiential occasions, followed by conversations and dialogues and reflection on what he had observed and done, gradually moving from oral to written expression.

The presence in the classroom of a small library, with illustrated books and "puppet theatre" (Figure 1), which, among its functions, also allowed the enrichment of the vocabulary and the improvement of expressive ability, completed the stimulations. With regard to the learning of reading and writing, the diary was used as an important communication tool (Colombo, Manicone, \& Zuccoli, 2017: pp. 212-224), self-correction or the search for errors to actively involve the children in learning, as well as the epistolary form (with the students of the school of Rome), reports and stories to narrate, describe and mentally re-elaborate the experiences and the work done up to understand the cause and effect relationships; and so at the "Rinnovata" a class calendar and the "big journal" ["Giornalone"] (Figures 2-4) were created to encourage the discovery and conscious construction of knowledge.

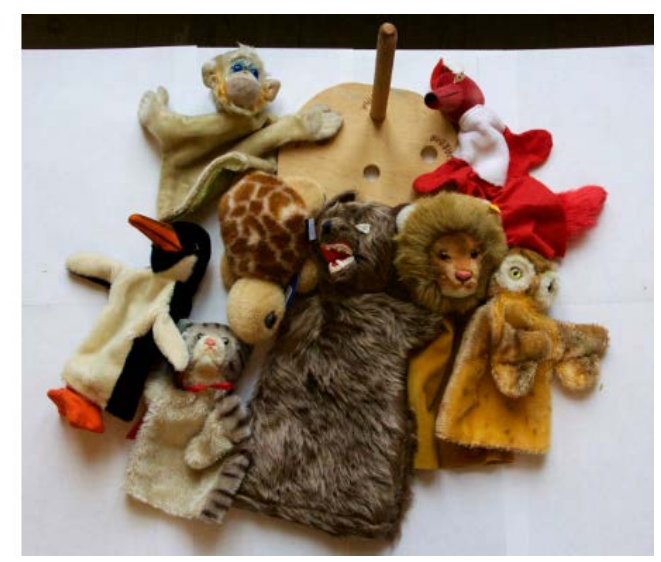

Figure 1. Puppets: Source: "Fondo Pizzigoni”. 


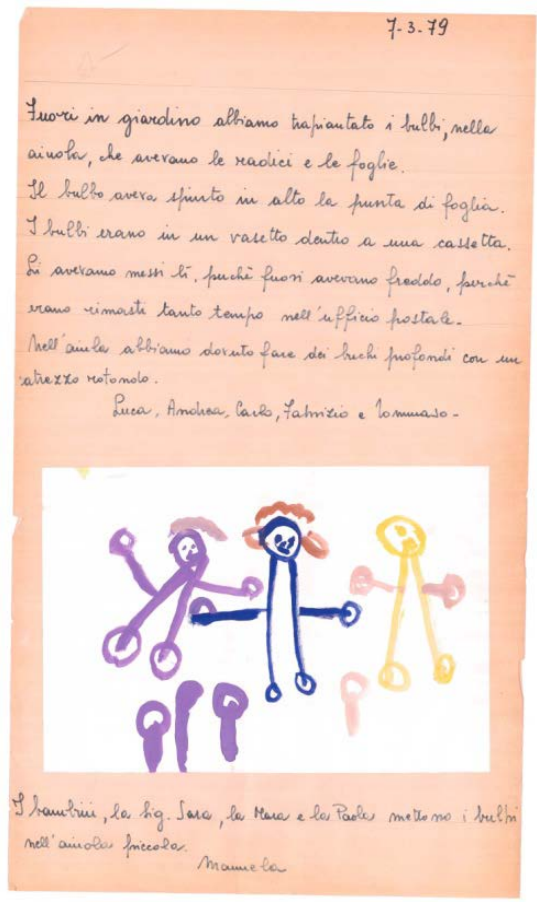

Figure 2. "Giornalone”. Source: "Fondo Pizzigoni”.

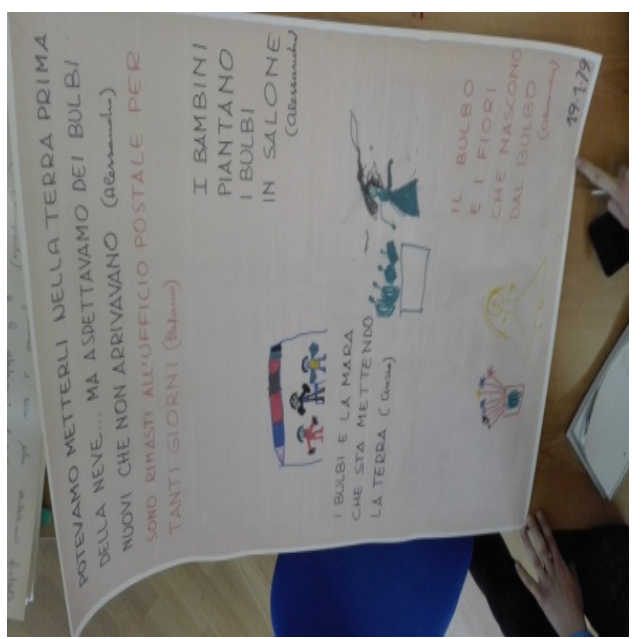

Figure 3. Examples of “Big JournaP”. Source: "Fondo Pizzigoni”.

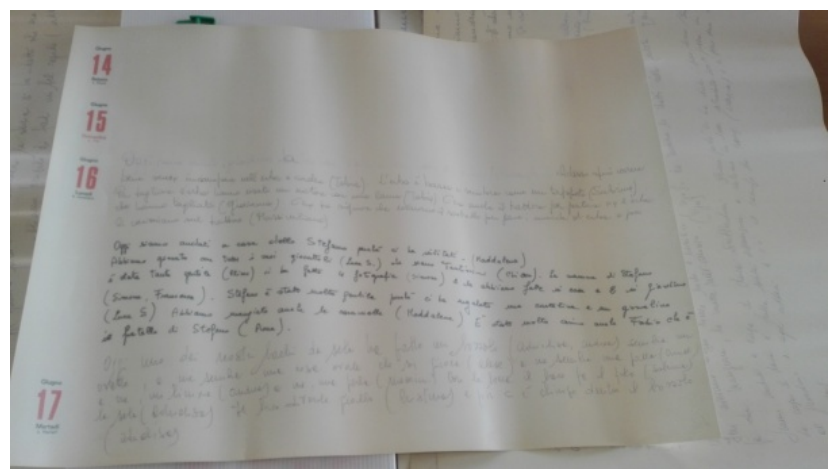

Figure 4. Examples of Calendar. Source: "Fondo Pizzigoni”. 
Pizzigoni gave importance to the design and implementation of teaching material, such as "series paintings", or billboards with illustrations arranged in series that reproduced scenes from the daily life of children to express judgments, evaluate and understand the temporal succession, develop the ability to tell and describe the facts, and to use the syllabary and movable type or images with the corresponding name underneath. This enabled the child to experience the need and practical utility of writing and reading (with a method and approach similar to the "global" one employed by Ovide Decroly (1962) to then arrive at the spelling). The need to learn a second language was also underlined, introducing "practical study of the French language" in teaching starting from class IV (remembering that Pizzigoni's father was a foreign language teacher), in which the conversation and the oral dimension and only then the grammar and the written dimension.

Regard to scientific knowledge, it was essential to start from the observation of reality, from the direct and personally lived experience of the child and from real problems or needs. In this sense, arithmetic, geometry and accounting were learned through observation and practical life activities, such as calculating class prices and expenses or for materials or travel, dividing and measuring land and flower beds, evaluating and calculate the amount of food to feed the animals, carry out the purchase and sale of products, record the sales made, calculate earnings percentages (activity that incorporates the economic mechanism in use in society), etc. Specifically, natural knowledge, as well as geographical (geography understood as knowledge of the world in which we live and the relationship between human and natural world) and historical, were faced and understood through outdoor life activities: gardening, travel, walks, trips, commemoration parties, visits to monuments, museums or castles, etc. and observing the natural landscape, so as to gradually pass from the mental representation of the surrounding space to more complex concepts and relationships. As emerges in the work Avventure nelforto e nel bosco [Adventures in the garden and in the wood] by Pierina Boranga, where we start from the stories about the fauna and flora of the garden and the wood, in order to learn the characteristics of these habitats in a fun way (Boranga, 1965).

Nature thus becomes an important source of education and design inspiration. Some educational materials designed by Pizzigoni are aimed at educating the senses and learning other concepts, such as size and shape, through pearls, or like the different shades of color through the wool threads with different shades (Figure 5). In addition, other teaching materials are used, such as abacus, geometric figures, coins, books with cropping exercises, composition of skits, etc. (Figure 6).

Particular attention in the program is also paid to physical education, which is carried out both outdoors and in contact with nature (with activities such as gardening, animal care, walks, etc.) and in an indoor gym with Swedish gymnastics equipment (benches, backrests...) and with breathing exercises, as well as the possibility of playing free and collective games and different sports (such as 


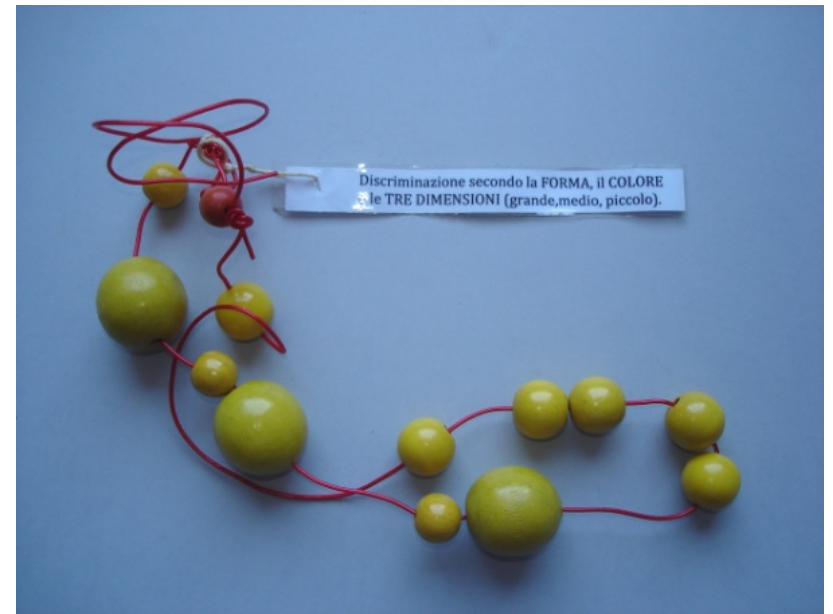

Figure 5. Educational material-pearls, for discrimination of form, colour and size. Source: "Fondo Pizzigoni".

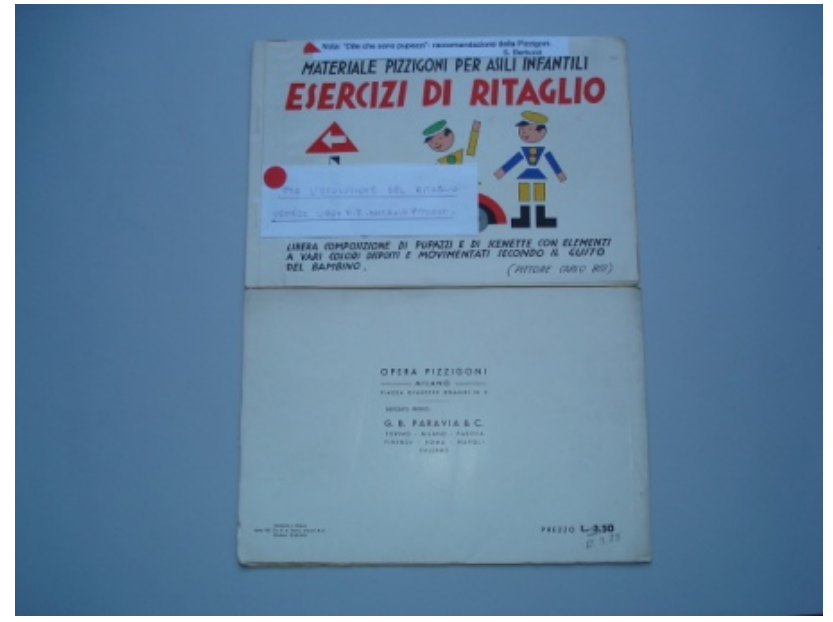

Figure 6. Teaching material-cropping exercises. Source: "Fondo Pizzigoni”.

swimming, rhythmic gymnastics, ball sports, skating, cycling, dancing etc.), in the awareness that physical and intellectual education are strongly linked to each other and that movement is among the basic needs of man. Thus, Pizzigoni (1930) argues that "physical education is a fact intimately linked to learning" (p. 17), coming to understand the current "psychomotor skills" over time. Food education and hygiene education were also linked to physical education with the aim of ensuring the development of a healthy lifestyle and the learning of healthy habits, so much so that checks on the cleanliness of the body in the morning. In addition to frequent medical checks throughout the school year, there is the compilation of a "biographical card" of each student, which focuses on the awareness of the link between mental and physical health and "the reform aims to give hygienic habits [...] for the evident purpose of responding to the legitimate request made to the school, to contribute to the protection of public health" (Pizzigoni, 1921: p. 3).

The goal is to combat sedentary lifestyle and disease, as opposed to traditional 
school, which focuses on immobility and the almost absence of physical education, reduced to two half hours a week. Even in the supplementary classes of professional start-up (from sixth to eighth, according to the provisions of the Gentile reform) space was dedicated to the orientation of the child towards a profession that was addressed by her interests and to hygiene habits in the various professions. In these classes, work was valued, specialized according to the interests of each student, industries were visited and labor legislation was known. All this made "Rinnovata" one of the "best means of hygienic propaganda" (Pizzigoni, 1921: p. 3), active and factual propaganda "that will produce healthy habits in the men of tomorrow" (Pizzigoni, 1921: p. 4).

Aesthetic education is also of fundamental importance, which is guaranteed by the "Rinnovata" through the care, beauty and orderliness of the school's furnishings, as there are vases with flowers, artistic statuettes and works of art in colour and black and white, mainly depicting scenes from everyday life, important people and natural landscapes, which develop the children's taste for beauty and aesthetic sense and encourage self-expression and creativity. A type of architecture, therefore, aimed at aesthetic education, which is cultivated through the contemplation of beauty in all its manifestations, including both the beauty of nature and art, including music, dance, rhythmic movement, singing and drawing. The latter, in particular starts with the observation of nature and the spontaneous work of the child and goes on to trace the figures of everyday objects and the representation of reality (such as leaves), projecting towards the application of laws of perspective.

Aesthetic and moral education are linked together, as we see from the fact that the three forms of beauty, such as order, clarity and simplicity, correspond to as many forms of moral education (interior order, goodness and sincerity). In the active school "mare of moral education" (Pizzigoni, 1931: p. 66), in nature, understood as a manifestation of divine power and wisdom, and in art we find the three constitutive values of education: the good, the beautiful and true. Puppet theater educates morally, aesthetically, socially and linguistically through the representation of the child's daily life experiences. In fact, the theater and the realization of comedies or dialogues allow the child to express himself, to overcome his fears and to self-educate himself, as well as having a liberating function (Chistolini, 2009b: pp. 25-30), as the "theater will please, will do good for the spirit and will instruct” (Pizzigoni, 1931: p. 71).

In addition to puppet theater, gardening and work (understood as a "forge of morality") favor and are means of both physical and moral education, as they allow you to experience feelings related to freedom, responsibility, patience, altruism, sense of duty, autonomy, justice, honesty, respect for others, etc. In fact, moral education, according to Pizzigoni, interpenetrates all didactic moments and is also linked to social education. Furthermore, at the "Rinnovata" there are neither punishments nor rewards, since the child learns from his own actions, experiences and related consequences, that is, from life. Discipline, therefore, is conceived as an "interpenetration of convictions, derived from interpenetration 
of spirits, and cannot be the result of the impositions of others. If so, it would not be discipline. What else is inner discipline, if not the complete and spontaneous adherence of our reason to a higher commandment [...] the feeling of discipline must therefore be a normal state, because it is constant in our spirit: it is our inner balance achieved. Internal discipline leads as consequence to external discipline" (Pizzigoni, 1931: pp. 43-44) and to the indissoluble union with freedom. Aesthetic education is here interpreted as the "moral elevation of the people" (Pizzigoni, 1930: p. 18) and therefore "wherever a source of beauty is the boy is brought, so that this beauty enters his spirit and remains for life" (Pizzigoni, 1930: p. 18).

Therefore, moral education also includes the education of "religious sentiment", where "everything that raises and purifies" (Rompato, 1927: p. 34) is part of it and is therefore an important factor of moral elevation, to the aim of "preparing a new generation stronger, healthier, more evolved than us" (Pizzigoni, 1910: p. 1). At the "Rinnovata" there were moments of prayer, religious songs, interior reflection and examination of conscience, which led to a progressive self-awareness, the teaching of biblical history and formal religious instruction for those who requested it, as Christian values, such as humility, forgiveness, respect for others, etc. they are also placed at the basis of social life, which leads to a religious education understood, in a broad sense, as the education of man. In fact, moral education also benefits from sexual education and coeducation of the sexes, according to which in the first two classes, from 6 to 8 years, males and females are educated together (this is a relevant aspect if we consider that the "Feminism" in Italy towards the end of the nineteenth century was still making its way), while subsequently they will be divided even if with moments of encounter on different occasions, such as music, walks, gardening, recreation etc. in order to enhance female activity and develop sex education, as well as healthy social relationships, based on mutual help, cooperation, respect between the two sexes, etc. It is thus a question here of guaranteeing the elevation of society and equality of rights and opportunities through a school for all that can implement a real democratization and regeneration of society (Cassottana, 2004: p. 125).

In this regard, Pizzigoni herself declares that "rich children will therefore have in school what they are looking for outside today; the poor will have what the rich enjoy, and which is not a luxury, but a physiological necessity of their age; children belonging to the middle class will have what they are generally deprived of today, and which is as indispensable to them as it is to others: physical education" (Pizzigoni, 1930: p. 14). Even towards children with disabilities or with problems and difficulties (for whom the "differential classes" were still present, subsequently abolished with the law of August 4, 1977), Pizzigoni had proposed its method and program since 1916 such as to respect the differences and uniqueness of each child to be implemented with the collaboration between teachers and doctors and the meticulous collection of data (Chistolini, 2009a: p. 162).

The effectiveness of the experimental method is evident from the reports of the inspectors themselves, such as Pellegrini, who states that "the teachers here 
do, indeed live the method" (Nicoli, 1947: p. 66) and "the internal time of the 'Rinnovata' is in short, a document of wise physiological, spiritual and scholastic economics" (1947: p. 68): "children think and learn because they work" (1947: p. 70). The results collected over time show how linguistic and expressive skills, as well as creativity are more developed in children who attend the "Rinnovata" than in those belonging to other schools.

Pizzigoni, therefore, emphasizes how it is necessary to create environments for the child where he feels free to express himself, since only in this way will it be possible to observe his authenticity and implement an educational action that starts from the conception of the child as a unique and unrepeatable person.

\section{The Pizzigoni "Rinnovata” School}

In 1911 Pizzigoni, after having created a Promoting Committee to translate its concept of school and to obtain the consent and the competition of the Municipality and the Government, acquired from the prefectural commissioner of the Municipality of Milan a land in the locality called "La Ghisolfa" on the road of the Bovisa and the use of a prefabricated pavilion, called "Döcker" (Figure 7), with a plaque where it was written Rinnovata "school according to the experimental method", suggested to Pizzigoni by the psychologist Zaccaria Treves.

This first Döcker granted by the commissioner became a refectory and a kitchen, while the second Döcker for the classrooms was granted by the director Felice Cottino. Both Döckers were refurbished and were equipped with sinks, toilets and showers, thanks to the help of the engineer Erminio Valverti. The latter, together with the gardener Sala, also took care of creating a playground and sports field and a field for agricultural exercises, as well as an apiary, a chicken coop and the planting of many trees and three cloisters, two small and covered for outdoor lessons and a large room with chairs and deck chairs for outdoor breakfast and rest. The Committee was responsible for furnishing the Döckers for the classrooms with individual tables and detached chairs, filing cabinets along the walls at child's height and where everyone could have their own place to place their works, while the decorations were entrusted to an artist.

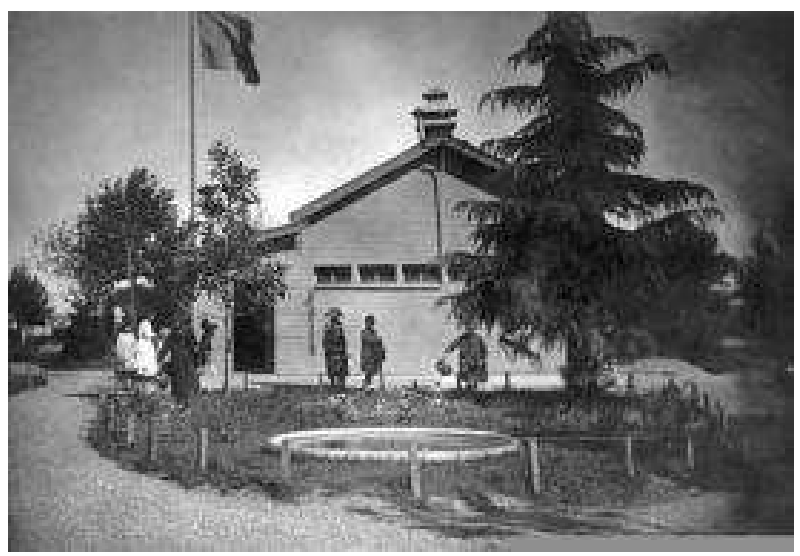

Figure 7. Döcker-Source: “Fondo Pizzigoni”. 
The Municipality, on the other hand, granted the school blackboards, chairs and cabinets for teachers. However, it should be emphasized that Pizzigoni's idea of how the "Rinnovata" should be was actually another namely a school "in which the child lived, as a poet, in sentiment and, as a scientist, in discovery" (Chistolini, 2009a: p. 49) inside a building located on one floor, where each classroom had an adjoining dressing room and opened directly onto the garden and corridor. In addition, large windows were needed, a covered gym with showers and toilets, a garden, two playing fields, a model field, that is, that of the teacher, an area for practical exercises, orchards, cloisters, service rooms, lighting, electricity and drinking water, a screening room, one for music and one for the museum and, finally, the refectory. The building was to be surrounded by land divided into garden, vegetable garden, two playgrounds, land for practical exercises, orchard, as well as chicken coop, rabbit hutch, fish tank, apiary and bird cage (Nicoli, 1947: p. 42).

Thus began the experiment with two mixed classes of first in the school year 1911-1912, until gradually the number of children did not increase, leading to new needs, which were realized with the construction of a new building on October 30, 1927 with the help of engineer Valverti. This building, which allowed Pizzigoni's original idea to be realized, had a total area of $20,781.134 \mathrm{~m}^{2}$ and was equipped with an entrance, an atrium, the management, the secretariat, a room for medical examinations, a teachers room, a refectory, a gym-theater, classrooms for teaching with adjoining changing rooms, classrooms for students with adjoining changing rooms open directly onto the garden and corridor, music room, projection room, pavilion for agricultural lessons, laboratories (mechanics, for shoemakers, carpenters, typography, etc.), pavilions for outdoor and agricultural lessons, playgrounds and gardens, stables and enclosures for animals (rabbit hutch, chicken coop, fish tank, etc.), tool shed, indoor swimming pool and, finally, classrooms with adjoining changing rooms and kitchen for the kindergarten, which was opened together with the nursery school in October 1927 (Nicoli, 1947: pp. 115-116).

This building from 1927 is still visible today and, despite some small changes (such as the reconstruction of the swimming pool), it is possible to admire the red bricks on the facades, the shape of the pitched roofs with Marseilles tiles and the wooden structure of the attic. A teacher of the "Rinnovata" describes the school as follows: "The beauty of the Pizzigoni 'Rinnovata' School is based on the details, to be admired and valued not only for the extreme rationality, elegance, complexity of the planimetric structure, but also for the smallest decorative elements: the exposed red bricks, the wooden beams, the tile roofs, the stuccos, the sober geometric figures created on each window [...] a school dreamed and built [...] for the joy of being able to implement, studying, building, experimenting, that passion for noble things and beauty, which accompanied his whole life" (Sacco, 2005: p. 1). Today the Pizzigoni Rinnovata School is a differentiated state primary school that follows the Pizzigoni method which has been extended over the last few years, following the establishment of the Comprehensive Institute, to 
the new classes of the nearby Dante Alighieri school. These places have survived great historical events, wars and socio-cultural and pedagogical changes that have occurred over time. From the experiences of the "Rinnovata" important innovations have been derived, which have been positively received, such as those related to technological development, with the birth of new laboratories, such as those of computer science, psychomotor skills, English etc. However, if the new social needs have transformed all this, what has remained intact from a distance is the original spirit of Pizzigoni's work, calibrated on respect for the child and on the experimental method.

The climate at "Rinnovata" is described accurately by Franca Zuccoli, teacher of the "Rinnovata", when she states that in it "pedagogy becomes concrete" (Zuccoli, 2004: p. 1) and it is allowed "to teach directly immersed in the disciplinary contents, experimenting and subsequently arriving at theorizing. Experimenting, reflecting and then discussing together to arrive at a shared knowledge, allowing oneself the time necessary to get to where the path of knowledge is leading us, are basic points that Giuseppina Pizzigoni had foreseen, and that sometimes escape us in the run-up. Of time and of the many destinations that seem most important to us [...] it is the world that strongly reminds you, with its fluctuating seasons, with the opportunities provided by the structure itself". In short, the "Rinnovata" can be defined as the first true outdoor school, "exemplary model of Italian active school" (Cassottana, 2014: p. 7), to use Pizzigoni’s words, in which "boredom and tiredness are banned [...] Work is held in high regard, because it is an intimate part of every notion imparted [...] here the child is free to do (Pizzigoni, 2012: p. 1). Pizzigoni expresses herself in this regard: "I am pleased to say that the "Rinnovata" school creates an environment of well-being, space, time, aesthetics and teaching means, for which easily, without effort or tedium on the part of schoolchildren and in a sympathetic way on the part of the teachers, the Ministerial Program can be carried out with profit" (Pizzigoni, 2012: p. 1).

\section{The Cultural and Educational Heritage between Past and Present}

Pizzigoni contributed to the renewal of the school and committed herself to transform it into a stimulating and happy environment for the education of children, a source of cognitive and affective well-being. Pizzigoni's thinking has come down to us and is still considered very relevant today, especially for the quality of her method and her way of understanding the child.

It is possible to trace in Pizzigoni's thought unavoidable educational elements, such as interculturalism, citizenship, civil coexistence, social relations, the relationship with the natural environment, respect for childhood and the child's person, the union between school and family, the provision of conditions for the overall development of the child, collaboration between teachers and the coincidence of the school with the world and the world with the school (Chistolini, 2008: pp. 31-38). Pizzigoni is a "Rinnovata" teacher who makes it clear that the 
school environment must encourage the acquisition of those basic tools to start interpreting the complexity that surrounds us (Musella, 2004). To do this, this environment must open up to the outside world, the real world, which today, even more than in the past, is to be understood as a multi-ethnic world. This leads the "Rinnovata" to set itself a new objective: intercultural education.

Pizzigoni's idea of the importance of education as a tool for the formation and improvement of humanity is also very much in evidence, as Cesare Scurati rightly points out when he argues that the "Rinnovata" becomes "the school of man as man in the broadest sense of his potential [...] school as 'educational community', that is to say a vital world capable of structuring itself in forms of organisational rationality aimed at promoting personal humanity" (Scurati, 2002: p. 1). Other innovative aspects that belong to this scholar's thinking are the autonomy of the school, the flexibility of the programme, respect for the needs, interests and rhythms of the child, the development of the student's transversal skills, the indissoluble link between theory and practice and the interdisciplinary nature of learning. Within the "Rinnovata", links were established starting from observation and direct experience of a fact and a plurality of educational interventions was followed in the desire to promote in children the development of critical thinking and problem solving to help them become future men and conscious citizens (Cassottana, 2004: pp. 226-229).

It is clear that "Rinnovata" constitutes an important segment of our cultural heritage, as emerges from the words of the Director of the School Office of Lombardy, Mario Dutto.

At the Symposium on 19 October 2002, Dutto launched the proposal to establish contact between the Pizzigoni school and those schools that are currently working on innovative hypotheses for the school system in order to gather the valuable experience of the past and compare it with the new school. In her opinion, the "Rinnovata" school can be in some way a reference point for doing school (Dutto, 2002). In the same way, Manuela Contoia underlines how activism, autonomy, cooperation and critical sense, which are elements present and characterizing learning in the "Rinnovata", had implications also from a psychological point of view, increasing the motivational level and the involvement of pupils, facilitating the organization of contents by placing them in the network of previous knowledge and experiencing first-hand the effectiveness and usefulness of what was learned.

This includes the acquisition and development of cognitive and metacognitive skills, different levels of social skills, and the continuity of learning experiences, both in school and out of school, as well as the ability to learn to ask questions about the why of things and to increase one's sensitivity to the investigation of one's inner world.

According to Romanini, Pizzigoni is placed in contemporary pedagogy above all for the inductive and self-sufficient character of her school pedagogy, understanding the self-sufficiency of the child as a "condition of living" (Romanini, 1958: p. 202), which cannot be lacking and which is effective only in the school: 
the self-sufficiency "that exists in the child as a child. We should, instead, put him in a position to live a proportionate life that is completely childlike and to carry out educational action in it, step by step" (Romanini, 1958: p. 197). It is just a question of the formation of the child who, by the miracle of the school, ceases "to be a schoolboy and a child to become 'man', a real and living person, aware of himself, not absorbable or atomized into masses" (Romanini, 1958: p. 28).

It is therefore of fundamental importance "to provide an education which accustoms man to enter into himself, to recognise and respect his personality, the rights of his spirit against the arrogance of his instincts" and "to lead man never to be satisfied with the 'how', but always to want to be aware of the 'why', as happens at the "Rinnovata" (Romanini, 1958: p. 35). All this is also testified by the fact that many pedagogues, such as Lombardo Radice and Luigi Credaro, have written and continue to write about Giuseppina Pizzigoni, with the desire to preserve and classify the numerous documents concerning her. Scholars such as Giovanni Gentile (for his idealism and artistic and religious teaching) also argued, in line with Pizzigoni, for the importance of renewing teaching. Rompato himself, a teacher at the "Rinnovata", sums up some principles in an effective and schematic way:

1) school helps the child to assert himself in life as a value;

2) life educates for life and school is a training ground for good habits and an environment of truth and beauty;

3) life is health and school aims to give society young people who are strong in body and spirit;

4) the economy of mental strength;

5) the learning programme is realised in school life, a life of experience, in which truth is a present, living reality, a continuous and spontaneous conquest of the spirit;

6) the programme is carried out by centres of interest in a unit;

7) work as a means of learning and good conduct, as well as of aesthetic, artistic, moral and religious education;

8) discipline as a habit of life (Rompato, 1927: p. 40).

Adolphe Ferrière in his work La scuola attiva [The active school] (1958) remembers the "Rinnovata" as a successful experiment of active school (Nicoli, 1947: p. 141) and Giuseppe Lombardo Radice in Lezioni di didattica e ricordi di esperienza magistrale [Didactic lessons and memories of master experience] (1950) declares that Pizzigoni's experiment is "one of the best centres of teacher training.

\section{The "Fondo Pizzigoni" and the "Opera Pizzigoni"}

Pizzigoni's merit is that it has claimed cultivable land for all children, even those from the city, as a formative teaching aid superior to any other" (Lombardo Radice, 1950: pp. 402-403). 
During her career Pizzigoni devoted herself not only to the creation of the "Rinnovata", but also to the training of teachers according to the experimental method and to its dissemination through the establishment of a Promotional Committee, conferences, speeches, internships and scholarships for teachers etc. (Cassottana, 1988: pp. 25-26). After the pedagogist left the school's management in 1929, convinced that it could "walk alone, without her direct guidance" (Cassottana, 1988: pp. 25-26), she devoted herself entirely to the dissemination of her method. The Promoting Committee was transformed into an "Association for the diffusion of the Pizzigoni method" in 1926, until it became a Moral Body with Royal Decree n. 2116 of 23 October 1927. It then became "Opera Pizzigoni" with the Royal Decree of 28th September 1933 n. 1460, with its seat in Milan, at the "Rinnovata" Pizzigoni school in Via Castellino da Castello n. 10 (Chistolini, 2020: p. 14). The "Opera Pizzigoni" has its own Statute and aims to:

1) disseminate the method and programme of Giuseppina Pizzigoni, taking into account the different needs of schools and places;

2) promote every year a Course of didactic differentiation according to the Pizzigoni method for the preparation of teachers;

3) assist the Direction of the Istituto Comprensivo "Rinnovata" Pizzigoni" of Milan in all that concerns the implementation of its programme;

4) conserve and preserve the Archives of Giuseppina Pizzigoni and the "Rinnovata" School;

5) promote the study of the Pizzigoni method;

6) welcome school groups visiting the Scuola "Rinnovata";

7) promote and maintain contacts with schools in Italy and Europe in order to begin experimenting with the Pizzigoni Method (from Opera Pizzigoni).

These aspects are contained in the Statute, in which all the characteristics of this Association are defined in detail, including the quota of the members, the organs of the Opera and their relative functions, the Governing Council and the Assembly of the members (from Opera Pizzigoni).

One of the points of the Statute foresaw the task of providing the Course of didactic differentiation according to the Pizzigoni method for the preparation of future teachers. In fact, Pizzigoni herself was involved in the training of teachers and fought for the establishment of such courses, so much so that as early as 1917 scholarships were financed for teachers coming out of the Normal Schools who committed themselves to spend a year at the "Rinnovata".

These courses took on, over time, different names including "Courses of educational differentiation according to the Pizzigoni method" and specific training courses were held for teachers in service from 1953-1954 until 1986-1987. In these years the last course was held with the address for kindergarten and the one for primary school, while the last course with the address only primary school was held in 1991-1992. The courses included a theoretical and a practical part and, in 1966-1967, the teachers had to submit a "Diario di tirocinio" [Training Diary]. 
In 1987, an aptitude test for admission was introduced and the completion of an "Entrance Questionnaire" with open and closed questions and personal information of the students was required, as well as the presentation, at the end of the course, of a "Report of Directed Apprenticeship" carried out in the nursery school (Chistolini, 2009a: pp. 79-80).

Despite the subsequent closure of these courses, the development and dissemination of Pizzigoni's method has continued over time thanks to the scientific work of Professor Sandra Chistolini and the fruitful activity of other teachers of the "Rinnovata" and of the Single cycle degree/Combined Bachelor and Master in Primary Teacher Education (Chistolini, 2009a: pp. 79-80). In fact, the dissemination of the method still continues today thanks to the "Fondo Pizzigoni" (Figure 8), created by Professor Sandra Chistolini at the Department of Education Sciences, University of Roma Tre, Via del Castro Pretorio, 20 Rome (Italy).

The collection comprises 389 books and 471 objects, located in room 0.14 and displayed in glass showcases and a large chest of drawers. The original Pizzigoni materials collected by Sara Bertuzzi (2007), teacher and headmistress of the "Rinnovata" kindergarten in Via Don Gnocchi in Milan, can also be consulted online thanks to the 456 descriptive cards present in the University Library System, in order to facilitate a wide consultation and dissemination, as well as a specific use for the training of future teachers (Chistolini, 2020: p. 16). In fact, the "Fondo Pizzigoni" collects 350 cards or records in 2012, increased to 450 in 2018 and 456 in 2020 and each of them identifies the object, the material, the document and the respective dnigitalized image, which can be accessed thanks to the bibliographic search of the Angelo Broccoli Library Catalogue.

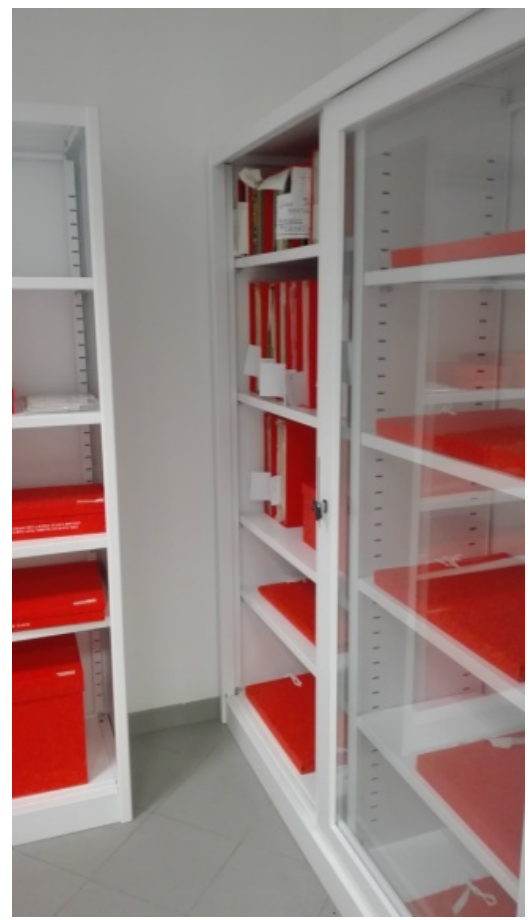

Figure 8. Aula "Fondo Pizzigoni University o Roma Tre". 
The cataloguing is based on three large collections of material: the first grouping relates to the didactic material produced and used by Pizzigoni, such as the pearls, the biographical report card, the cutout exercises, etc.; the second grouping relates to the material produced by the kindergarten children and their drawings, school or class journals and calendars; finally, the third grouping relates to the works of the Pizzigoni school. The second group of material includes the productions of the children of the nursery school and their drawings, school or class newspapers and calendars. Finally, the third group of material includes the works of the teachers and school leaders, the reports or themes of Pizzigoni's training courses, observation sheets, teaching materials and work plans kept by Sara Bertuzzi (2007). These materials represent a true living testimony of what was achieved from 1953 to 1986 in various nursery schools in Milan (in via Don Gnocchi, via Valdagno, via Capecelatro), in line with Pizzigoni's thinking and the teaching materials she created.

As Chistolini states, the research "on Giuseppina Pizzigoni's school is part of a wide scientific survey on schools of method started in 1987 at the Chair of Prof. Mauro Laeng [...]. The origin of the "Fondo Pizzigoni" began around 2007 after several years of research and study that came together in the heritage preserved by Sara Bertuzzi (2007) and also represented by Giuseppina Pizzigoni's original teaching documents and materials" (Chistolini, 2020: p. 13), so that they could be made available to young teachers.

Sara Bertuzzi (1922-2016) worked as an educator at the "Rinnovata" from 1956 until 1967 and became headmistress at the Milan nursery schools in via Valdagno, via Don Gnocchi and via Capecelatro from 1968 to 1986. She became an active member of the Opera Pizzigoni, obtaining from the latter and from the directors and experts of the experimental method of the "Rinnovata" Pizzigoni School in Milan, who considered her "the only expert in the application of the method in the nursery school, now a kindergarten" (Chistolini, 2020: p. 9). Sara Bertuzzi donated her materials to the "Fondo" from 2009 onwards to make them accessible to teachers and future teachers.

The "Fondo Pizzigoni" is to be understood as a pedagogical heritage of "documents on the Pizzigoni experimental method in pre-schools [...]. Nowhere in the world is there a 'Fondo' like this one, dedicated to the productions of children and their teachers, with digitisation of most of the materials, with online connection to the University Library System. Everyone can find out about it through the detailed description in each card in the catalogue [...]. The Faculty of Education approved the establishment of the 'Fondo' in the Council of 17/7/2012" (Chistolini, 2020: pp. 14-15). Sandra Chistolini explains why she has sought to enhance the pedagogical work of teachers and children: "I have prevented the destruction of the culture of childhood and I have allowed this heritage to enter the University where I work, so that everyone can know, see and touch what has been restored in schools all over the world through Giuseppina Pizzigoni's experimental method" (Chistolini, 2020: p. 15). 
On the subject of Sara Bertuzzi Chistolini says she met her at the primary school conference La Rinnovata: ieri, oggi, domani. Un metodo per la scuola di sempre [The Rinnovata: yesterday, today, tomorrow. A method for the school of all time], held in Milan on 5-6 October 2007 [...]. Sara, a faithful disciple of Giuseppina Pizzigoni, was able to "interpret and expand on the original experimental method. Her extraordinary intuitive ability, her delicate professional seriousness, and above all, her enormous love for children, I believe, constituted her identity. Linked to Pizzigoni and, at the same time, autonomous with respect to Pizzigoni, Sara understood that the educator takes on a precious task for the whole of humanity, as she introduces children to the world of that true and fair knowledge on which our being good citizens depends [...]. Sara Bertuzzi is Italian pedagogical culture, not just part of it. Sara is culture in the sense that she continues to be with us [...]. Thanks to the wall newspapers and the big newspapers, we can now understand what the children of half a century ago were thinking and we can scientifically understand the change in the minds, ways of reasoning and feeling of three-, four- and five-year-olds. We have something invaluable for the knowledge of childhood" (Chistolini, 2020: pp. 321-322).

Pizzigoni herself recalls the five fundamental reasons that stimulated the process of pedagogical reform:

1) the first reason lies in the criticism of verbalism, which deprives children of factual activity and does not lead to true knowledge;

2) the second reason stems from the lack of balance between the psychic and physical needs of childhood and the needs that school requires to be followed;

3 ) the third reason stems from the idea that school does not prepare for life, but opens the mind to reasoning, broadens the horizons to give meaning to one's life and teaches children to choose responsibly what to do when they grow up;

4) the fourth reason lies in the criticism of the time children spend at school, so much so that at the "Rinnovata" the time is extended;

5) the fifth reason concerns the high number of pupils in each section, which does not encourage the individual activity indispensable to the study of the discipline that prepares for a sense of responsibility and social life (Chistolini, 2020: pp. 21-25).

In the "Fondo Pizzigoni" there are also the seven handwritten diaries, dating from 1954 to 1967, of Sara Bertuzzi, who wrote in ruled and squared notebooks the monthly programme, the children's reflections, critical comments and the didactic activities from October to June (Chistolini, 2020: p. 33).

In Sara Bertuzzi's reports and diaries it is clear that the various activities are carried out continuously without any difficulties on the part of the children and that key concepts such as respect for childhood and its time are reiterated (Chistolini, 2020: p. 69). Sara also explains the importance of time and the use at school of "newspaper and calendar practice so that dates, facts and events come to stimulate narratives, to determine conversations, research, experiences, to offer the cue to underline [...] all those suggestions and suggestions that are in tune 
with the child's eagerness to discover and that are alive and valid if they originate from immediate interests, if proposed by facts" (Chistolini, 2020: p. 126). The newspaper is intended to be "a lively and dynamic means because it is dictated by the facts experienced by the children, to develop and exercise memory, reflection, association and expression. It is combined with the calendar to complete the experience of the weather" (Chistolini, 2020: p. 133), as are the other experiences involving the observation of weather phenomena and nature, which are "always a hymn of joy to the wonders that surprise and delight children. While observing, one discovers the real facts and explanations flow smoothly" (Chistolini, 2020: p. 61).

\section{Conclusion}

The "Fondo Pizzigoni" writes every day to spread the experimental method not only in Italy, but also abroad. Over time, schools have arisen that recover the architecture and the method of the "Rinnovata", such as the one created in 1934 in Belluno by Piera Boranga, the one created in Palermo thanks to the direction of Enrico Ferrara, the one born in Ravenna thanks to the inspector Gastone Foggi and the teacher Bersotti and, finally, those of Trenno-Lampugnano and Valdarno (Nicoli, 1947: pp. 119-123). The diffusion of Giuseppina Pizzigoni's experimental method still takes place today thanks to the continuous scientific contribution of those who with their publications in different languages help to understand this important Italian pedagogical figure in the world.

\section{Conflicts of Interest}

The author declares no conflicts of interest regarding the publication of this paper.

\section{References}

Bertuzzi, S. (2007). Ottant'anni dall'istituzione dell'asilo infantile di Giuseppina Pizzigoni. Intervento al Convegno per gli Ottanta anni della "Rinnovata" del 5-6 ottobre 2007. http://www.operapizzigoni.it/testi-su-metodo-"Rinnovata"/90-sara-bertuzzi-ottantanni dallistituzione-dellasilo-infantile-di-giuseppina-pizzigoni

Boranga, P. (1925). La natura e il fanciullo. Guida agli educatori per far conoscere ed amare la natura al fanciullo. Torino: G. B. Paravia \& C.

Boranga, P. (1965). Avventure nell'orto e nel bosco. Firenze: Vallecchi.

Cassottana, R. (1988). Giuseppina Pizzigoni: Oltre il metodo la "teorizzazione nascosta". Brescia: La Scuola.

Cassottana, R. (2004). Giuseppina Pizzigoni e la "Rinnovata" di Milano. Tradizione e attualità per la scuola primaria. Brescia: La Scuola.

Cassottana, R. (2014). L’Attivismo e la figura di Giuseppina Pizzigoni. Riletture critiche. Rivista Formazione, lavoro, persona, 4, 1-27.

Chistolini, S. (2008). L'asilo della Pizzigoni per la pedagogia contemporanea. Il Nodo-Scuole in rete, 11, 31-38.

Chistolini, S. (2009a). L'asilo infantile di Giuseppina Pizzigoni. Bambino e scuola in una 
scuola pedagogia femminile del Novecento. Milano: FrancoAngeli.

Chistolini, S. (2009b). Etica ed estetica nella scuola dell'infanzia di ispirazione pizzigoniana. Le Nuove Frontiere della Scuola, 7, 25-30.

Chistolini, S. (2016). Pedagogia della natura. Pensiero e azione nell'educazione della scuola contemporanea: Asilo nel bosco, Jardim Escola João de Deus, Outdoor education. Milano: FrancoAngeli.

Chistolini, S. (2020). Il Fondo Pizzigoni. Metodo sperimentale e scuola dell'infanzia nei Diari di Sara Bertuzzi. Milano: FrancoAngeli.

Codignola, É. (1948). Le "Scuola Nuove" e i loro problemi. Firenze: La Nuova Italia.

Colombo, R., Manicone, G., \& Zuccoli, F. (2017). Leggere con “metodo”. Una riflessione sulla relazione tra metodo Pizzigoni e l'apprendimento della lettura e della scrittura. Form@re. Open Journal per la formazione in rete, 22, 212-224.

De Bartolomeis, F. (1953). Giuseppina Pizzigoni e la "Rinnovata”. Firenze: La Nuova Italia.

Decroly, O. (1962). La funzione di globalizzazione e l'insegnamento. Firenze: La Nuova Italia.

Dutto, M. (2002). La "Rinnovata” Pizzigoni. Per la scuola elementare italiana: tradizione e Prospettive. Intervento al Simposio del 19 ottobre 2002.

http://www.operapizzigoni.it/testi-su-metodo-"Rinnovata"/76-mauro-dutto-intervento al-simposio

Ferrière, A. (1958). La scuola attiva. Firenze: Marzocco.

Fondo Pizzigoni. https://www.fondopizzigoniscuolainfanzia.it/

Frabboni, F. (2002). Riforma, innovazione e sperimentazione: Il modello di Giuseppina Pizziogni. Intervento al Simposio tenuto il 19 Ottobre 2002. Milano: “Opera Pizzigoni”. http://www.operapizzigoni.it/

Friso, L. (2017). Un esperimento didattico italiano. La Scuola Rinnovata secondo il metodo sperimentale. Estratto dalla Rivista pedagogica diretta da Luigi Credaro, 10, 3.

Fröbel, F. W. A. (1993). L'educazione dell'uomo (1826). Firenze: La Nuova Italia.

Lombardo Radice, G. (1925). Dove i bambini ci dicono che cosa sia 'La "Rinnovata" , Estratto da "La scuola in Lombardia". Milano: Arti grafiche Stella.

Lombardo Radice, G. (1950). Lezioni di didattica e ricordi di esperienza magistrale. Firenze: Edizioni Remo Sandron.

Musella, D. (2004). Dalla scuola al mondo. Intervento alla Tavola Rotonda "Gli ambienti della "Rinnovata": Ieri, oggi, domain" del 29 maggio 2004.

http://www.operapizzigoni.it/testi-su-metodo-"Rinnovata"/71-donatella-musella-dallas cuola-al-mondo

Nicoli, P. F. (1947). Storia della scuola “Rinnovata”. Milano: Ufficio di Propaganda dell” "Opera Pizzigoni".

Opera Pizzigoni (1927). http://www.operapizzigoni.it/

Pestalozzi, J. H. (1931). Antologia pestalozziana. M. Masante (Ed.) Torino: SEI-Società Editrice Internazionale.

Pizzigoni, G. (1910). Appunti di G. Pizzigoni del 1910: Donazione dalla prof.ssa Olga Rossi Cassottana in Convegno del 14 giugno 2005.

http://www.operapizzigoni.it/scrittidi-g-pizzigoni/106-appunti-di-g-pizzigoni-del-1910

Pizzigoni, G. (1911). La Scuola "Rinnovata” secondo il metodo sperimentale. Discorso tenuto nell'aula Magna del Ginnasio Beccaria. Milano: Stab. D’arti grafiche A. Bertarelli $\& \mathrm{C}$. 
Pizzigoni, G. (1912). Relazione sulla scuola "Rinnovata” di Milano del 1912. http://www.operapizzigoni.it/scritti-di-g-pizzigoni/107-relazione-della-scuola”Rinnova ta"-1912

Pizzigoni, G. (1914a). La scuola elementare "Rinnovata" secondo il metodo sperimentale. Milano: G.B. Paravia \& C.

Pizzigoni, G. (1914b). La Scuola Rinnovata secondo il metodo sperimentale. In Conferenza tenuta alla $R$. SocietàItaliana d'Igiene (p. 6), Milano.

Pizzigoni, G. (1920). L'insegnamento oggettivo. In Estratto dalla "Rivista pedagogica” diretta da Luigi Credaro (Vol. 13, pp. 3-4). Milano-Roma-Milano: Società editrice Dante Alighieri.

Pizzigoni, G. (1921). La Scuola "Rinnovata" ai fini della propaganda igienica. In editor, Estratto dal n. 22 del giornale "L'Italia sanitaria”. Roma: Stab. Poligrafico Editoriale Romano di E. Negri \& C.

Pizzigoni, G. (1922). Linee fondamentali e programmi della scuola elementare "Rinnovata" secondo il metodo sperimentale. Milano: G.B. Paravia \& C.

Pizzigoni, G. (1929). Il mio Asilo infantile. Linee fondamentali. Programma. Orario. Note illustrative. Milano: Stab. Tipo-Litogr. Cartotecnico Fed. Sacchetti \& C.

Pizzigoni, G. (1930). La Scuola “Rinnovata” secondo il metodo sperimentale. Croce Rossa Italiana. Comitato centrale, No. 31. Reggio Emilia: Tipografia di Ettore Ferraboschi.

Pizzigoni, G. (1931). Le mie lezioni ai maestri delle scuole elementari d'Italia. Milano: Ufficio di Propaganda della "Rinnovata".

Pizzigoni, G. (1940). Il lavoro nelle cinque classi elementari della scuola "Rinnovata" di Milano. Milano: Opera Pizzigoni.

Pizzigoni, G. (1946). La storia della mia esperienza o Come l'Autrice vide nel suo spirito il rinnovamento della Scuola Elementare d'Italia. Milano: Ufficio di propaganda dell'Opera Pizzigoni.

Pizzigoni, G. (2012). Relazione sulla scuola Rinnovata di Milano del 1912 (p. 1). http://www.operapizzigoni.it/scritti-di-g-pizzigoni/107-relazione-della-scuola-rinnovat $\underline{\mathrm{a}-1912}$

Pizzigoni, G. (2013). Il mio diario. Martinsicuro: Di Felice.

Romanini, L. (1958). Giuseppina Pizzigoni e la prima realizzazione di una pedagogia scolare autosufficiente. Brescia: La Scuola.

Rompato, E. (1927). I principî della "Scuola 'Rinnovata' "della Ghisolfa. Milano: Ufficio di Propaganda dell'Assessorato per la diffusione del metodo Pizzigoni.

Sacco, L. (2005). Scheda storica della Scuola "Rinnovata".

http://www.operapizzigoni.it/testi-sumetodo-"Rinnovata"/96-lucia-sacco-scheda-storic a-della-scuola-"Rinnovata"

Scurati, C. (2002). Cesare Scurati Pedagogia per la scuola primaria. http://www.operapizzigoni.it/testi-sumetodo-"Rinnovata"/119-cesare-scurati-pedagogi a-per-la-scuola-primaria-2002

Zuccoli, F. (2004). II “Metodo Pizzigoni" oggi e presentazione della "Rinnovata”. http://www.operapizzigoni.it/testi-su-metodo-"Rinnovata"/73-franca-zuccoli-il-metod opizzigoni-oggi-e-presentazione-della-"Rinnovata"-12-2004 